\title{
PERANCANGAN TEKNOLOGI REVERSE OSMOSIS DENGAN MEMANFAATKAN AIR EFLUEN PENGOLAHAN AIR LIMBAH SEBAGAI BAHAN BAKU DALAM UPAYA MENGEFISIENSIKAN PEMAKAIAN AIR BERSIH DARI KAWASAN INDUSTRI MM2100
}

(Studi Kasus pada PT Yutaka Manufacturing Indonesia)

\author{
M. Yani Syafei ${ }^{1}$, Burhan Primanintyo ${ }^{2}$ dan Mohamad Nur Isnanda ${ }^{3}$ \\ Jurusan Teknik Industri, Fakultas Teknik Universitas Presiden \\ Jl. Ki Hajar Dewantara Kota Jababeka,Cikarang, Bekasi - Indonesia 17550 \\ 1'yanisyafei@president.ac.id, ${ }^{2}$ burhanp@president.ac.id, 3nandolactobacillus@gmail.com
}

\begin{abstract}
Abstrak: PT. YMI adalah salah satu perusahaan yang bergerak dibidang otomotif untuk kendaraan roda dua. Perusahaan ini sebagai bagian dari grup Astra berusaha untuk menjadi sebuah "Green Company" melalui program AGC (Astra Green Company) dimana salah satu penilaiannya adalah adanya program recycle air limbah sebanyak $30 \%$ per bulan yang tujuannya adalah penghematan atau efisiensi pemakaian air bersih. Teknologi yang digunakan untuk pemurnian air efluen pengolahan air limbah memanfaatkan teknologi Reverse Osmosis dengan treatment awal menggunakan proses Resin Kation, Karbon Aktif dan Mikrofiltrasi. Membran yang digunakan untuk sistem Reverse Osmosis ini adalah Filmtec 30-4040 TW/BW. Hasil dari penerapan teknologi Reverse Osmosis terhadap pemakaian air bersih di PT YMI adalah sebesar 34,99\% dimana keberhasilan ini dapat tercapai dikarenakan adanya daur ulang air efluen yang ikut berkontribusi sebesar $100 \%$. Selain itu, terdapat pula keuntungan yang diperoleh dari tidak adanya pembuangan air efluen kedalam kawasan industri. Biaya pemasukan yang diperoleh sebesar $\mathrm{Rp} 23.591 .675,-$ / bulan. Untuk biaya pengeluaran (pemakaian energi listrik, biaya spare part dan upah lembur) sebesar Rp 11.470.172,- / bulan sehingga keuntungan yang diperoleh sebesar Rp 12.121.503,- / bulan. Payback Period untuk sistem R.O ini akan tercapai selama 24 bulan atau 2 tahun.
\end{abstract}

Kata Kunci: Air Efluen Pengolahan Air Limbah, Reverse Osmosis, Mikrofiltrasi, Payback Period, Resin Kation.

\begin{abstract}
PT. YMI is one of the automotive manufacturers for two-wheeled vehicles. As a part of the Astra Group, the company strives to become a "Green Company" through the AGC (Astra Green Company) program. One of its assessments is a $30 \%$ wastewater recycle program per month which aims to save or use clean water efficiently. The technology used for purification of effluent water from waste water treatment is by Reverse Osmosis technology with initial treatment by using Cation Resin, Activated Carbon and Micro-filtration process. The membrane used for this Reverse Osmosis system is the Filmtec 30-4040 TW/BW. The result of the application of Reverse Osmosis technology to clean water usage in PT. YMI is $34.99 \%$ which this success can be achieved due to the recycling of effluent water contributing 100\%. In addition, there are also benefits obtained from the absence of effluent water into the industrial estate. Income fee earned amounted to Rp 23,591,675, - / month. For expenses (electricity usage, spare part and overtime) Rp 11.470.172, - / month so the profit earned is Rp 12.121.503, - / month. Payback Period for this R.O. system will be achieved for 24 months or 2 years.
\end{abstract}

Keywords: Effluent Water from Waste Water Treatment, Reverse Osmosis, Micro-filtration, Payback Period, Cation Resin.

\section{PENDAHULUAN}

\section{Latar Belakang Penelitian}

PT Yutaka Manufacturing Indonesia (YMI) sebagai perusahaan yang bergerak di bidang industri komponen otomotif dimana dalam proses produksi dan support produksinya menggunakan air. Air yang digunakan dibagi menjadi dua bagian, yaitu : air untuk kebutuhan produksi, contohnya untuk mendinginkan mesin, mencuci mesin, dan lain-lain. Sedangkan Air untuk kebutuhan support produksi, contohnya untuk menyiram tanaman, flushing toilet, cuci tangan, wudhu, pencucian kendaraan dan untuk keperluan cleaning service. Air di PT YMI di pasok dari Kawasan Industri MM2100 dimana setiap bulannya ada biaya yang harus dibayarkan oleh perusahaan sejumlah aktual pemakaian air. Data pemakaian air bersih dan pembuangan 
air efluen PT YMI selama Januari - Juni 2016 tersaji pada gambar 1. Data rata - rata pemakaian air bersih secara keseluruhan di PT. YMI untuk semester pertama tahun 2016 adalah $5.172,83 \mathrm{~m}^{3}$, dimana harga untuk pemakaian air bersih dari Kawasan MM2100 sebesar 0,45 USD per $\mathrm{m}^{3}$. Sedangkan data rata - rata pembuangan air efluen secara keseluruhan di PT. YMI untuk semester pertama tahun 2016 adalah $1.696,83 \mathrm{~m}^{3}$, dimana harga untuk pembuangan air efluen ke Kawasan MM2100 dikenai biaya sebesar 0,55 USD per $\mathrm{m}^{3}$, sehingga total biaya rata-rata per bulan yang dikeluarkan oleh perusahaan untuk pemakaian air bersih dan pembuangan air efluen sebesar $\mathrm{Rp}$ 44.023.904 (dengan asumsi 1 USD $=\mathrm{Rp}$ 13.500).

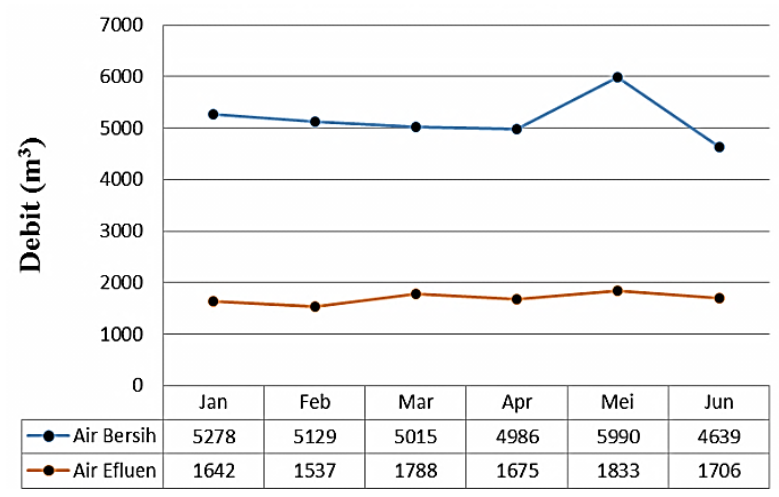

Gambar 1. Grafik Air Bersih dan Efluen PT YMI (Sumber : Laporan Bulanan Seksi FP dan WT Tahun 2016)

PT YMI sebagai bagian dari grup Astra berusaha untuk menjadi "Green Company" melalui program AGC (Astra Green Company) dimana salah satu penilaiannya adalah adanya program daur ulang air limbah sebesar $30 \%$ per bulan yang tujuannya untuk penghematan atau efisiensi pemakaian air. Disamping hal itu, untuk bersaing di era globalisasi, maka manajemen juga menargetkan adanya penghematan energi minimal $5 \%$ per bulan, termasuk diantaranya adalah penghematan atau efisiensi pemakaian air. Diharapkan dengan penerapan teknologi reverse osmosis, dapat berakibat pada semakin rendahnya biaya pemakaian air bersih dan pembuangan air efluen di perusahaan yang mana sepaham dengan target dari management dan tuntutan kebijakan lingkungan.

\section{Tujuan Penelitian}

Dalam penyusunan penelitian ini, ada beberapa tujuan yang ingin dicapai, yaitu sebagai berikut :

1. Mengetahui teknologi yang tepat digunakan dalam upaya efisiensi air bersih.

2. Mengetahui dampak yang ditimbulkan setelah dilakukannya penerapan teknologi reverse osmosis terhadap biaya pemakaian air bersih dari kawasan industri.

3. Mengetahui dampak yang ditimbulkan dari penggunaan teknologi reverse osmosis terhadap beberapa biaya untuk setiap bulannya seperti : pengeluaran (operasional dan spare part), pemasukan, dan keuntungan.

\section{METODE YANG DIGUNAKAN}

Untuk dapat melakukan penelitian ini, maka data yang diperlukan adalah data pemakaian air bersih, data biaya pembuangan air efluen pengolahan air limbah, data nilai parameter air efluen pengolahan air limbah (WWT), serta data spesifikasi sistem RO (Reverse Osmosis). Data-data tersebut akan dihitung dan dianalisis menggunakan metode-metode di bawah ini:

\section{Teknologi Reverse Osmosis}

Reverse Osmosis (R.O) adalah suatu proses pembalikan dari proses osmosis. Peristiwa osmosis (Gambar 2)

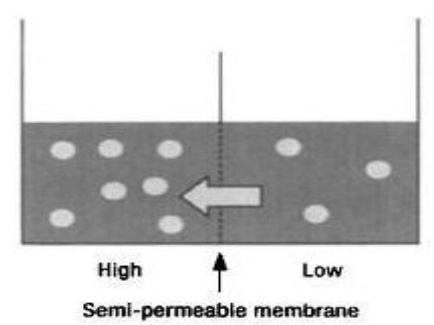

Gambar 2. Proses Osmosis (Sumber : Jane Kucera, 2010, Reverse Osmosis Industrial Aplication) 
adalah proses perpindahan larutan dari larutan dengan konsentrasi zat terlarut rendah menuju larutan dengan konsentrasi zat terlarut lebih tinggi sampai terjadi kesetimbangan konsentrasi (Kucera, 2010:14).

\section{Analisis Kelayakan Investasi}

Aspek finansial atau aspek keuangan dalam studi kelayakan merupakan aspek yang digunakan untuk menilai keuangan perusahaan secara keseluruhan (Hutasoit, 2011:40). Penentuan kelayakan suatu usaha berdasarkan kriteria investasi dapat dilakukan melalui pendekatan dengan menggunakan alat ukur, yaitu (Osterwalder, 2012:88):

\section{Payback Period (PP)}

Payback Period adalah suatu metode berapa lama investasi akan kembali atau periode yang diperlukan untuk menutup kembali pengeluaran investasi (initial cash investment) dengan menggunakan aliran kas, dengan kata lain payback period merupakan rasio antara initial cash investment dengan cash flownya yang hasilnya merupakan satuan waktu. Suatu usulan investasi akan disetujui apabila payback period-nya lebih cepat atau lebih pendek dari payback period yang disyaratkan oleh perusahaan. Rumus payback period jika arus kas dari suatu rencana investasi atau proyek sama jumlahnya setiap tahun. Secara matematik rumusnya adalah sebagai berikut :

Payback Periode $=\frac{\text { Investasi Awal }}{\text { Benefit-Opeational }} \ldots$ pers.(1) Keunggulan metode ini adalah sebagai berikut (Osterwalder, 2012:92) :

a. Perhitungannya mudah dimengerti dan sederhana.

b. Mempertimbangkan arus kas dan bukan laba menurut akuntansi.

\section{Net Present Value (NPV)}

Metode ini adalah metode yang mengurangkan nilai sekarang dari uang dengan aliran kas bersih operasional atas investasi selama umur ekonomis termasuk terminal cash flow dengan initial cash flow (initial investment). Secara matematik rumus untuk NPV :

$\mathrm{NPV}=-\mathrm{I}+\mathrm{AB}(\mathrm{P} / \mathrm{A}, \mathrm{i}, \mathrm{N})+\mathrm{S}(\mathrm{P} / \mathrm{F}, \mathrm{i}, \mathrm{N})-$
$\mathrm{AC}(\mathrm{P} / \mathrm{A}, \mathrm{i}, \mathrm{N})-\mathrm{OH}_{\mathrm{n}}(\mathrm{P} / \mathrm{F}, \mathrm{i}, \mathrm{N}) \ldots \ldots \ldots$..... pers. $(2)$

Dimana :

I : Nilai investasi awal

AB : Keuntungan yang diperoleh per tahun

AC : Biaya perawatan per tahun

$\mathrm{S} \quad$ : Nilai sisa alat

$\mathrm{OH}_{\mathrm{n}} \quad$ : Biaya perbaikan pada tahun ke-n

i : Suku bunga

$\mathrm{N} \quad$ : Umur ekonomis

P/A : Present Worth Uniform Series

Payment

P/F : Present Worth Single Payment.

Kriteria keputusan penggunaan metode NPV adalah sebagai berikut (Osterwalder, 2012:110) :

- Jika NPV bertanda positif (NPV > 0), maka rencana investasi diterima.

- Jika NPV bertanda negatif (NPV < 0), maka rencana investasi ditolak.

Keunggulan dari metode NPV adalah (Osterwalder, 2012:115) :

1. Memperhitungkan nilai waktu dari uang.

2. Memperhitungkan arus kas selama usia ekonomis proyek.

3. Memperhitungkan nilai sisa proyek.

\section{Perancangan Teknologi Pengolahan Air dan Analisis Biaya}

Setelah seluruh data telah didapatkan dan analisis kelayakan investasi sudah dilakukan maka yang hal yang dilakukan selanjutnya adalah sebagai berikut:

1. Perancangan Teknologi Pengolahan Air Dari hasil analisis kelayakan investasi, kemudian dilakukan perancangan teknologi pengolahan air bersih yaitu merancang tata letak sistem pengolahan air, saluran pipa, dan bak penampungan air hasil pengolahan. Setelah rancangan jadi, kemudian mencari beberapa subkontraktor untuk melakukan tender harga. Dan subkontraktor yang terpilih berhak atas pengerjaan proyek ini. 


\section{Analisis Data}

Setelah data-data dikumpulkan, maka dilakukan pengolahan seperti :

a. Menghitung pencapaian target efisiensi pemakaian air bersih dan pembuangan air efluen.

b. Menghitung biaya operasional (biaya listrik dan spare part) dan biaya pemasukan sehingga diperoleh keuntungan dari pengoperasian teknologi pengolahan air.

\section{Evaluasi Hasil}

Dengan mengukur hasil pengolahan air limbah dari segi kemampuan dalam menurunkan sifat fisika, kimia dan, biologi. Alat pengendalian kualitas dari teknologi ini berupa instruksi kerja, checksheet dan jadwal preventif.

\section{HASIL DAN PEMBAHASAN \\ Pemilihan Alternatif Teknologi}

Pemilihan alternatif teknologi untuk proses pengolahan air bersih yang memanfaatkan air efluen WWT PT.YMI sebagai bahan baku harus memperhatikan berbagai aspek yang berguna untuk mendukung proyek ini. Pemilihan alternatif teknologi tersaji pada tabel 1,

Tabel 1. Alternatif Teknologi Pengolahan Air

\begin{tabular}{|c|c|c|c|c|c|c|}
\hline \multirow{2}{*}{$\begin{array}{l}\mathbf{N} \\
\mathbf{O}\end{array}$} & \multirow{2}{*}{$\begin{array}{l}\text { ALTERNATIF } \\
\text { TEKNOLOG }\end{array}$} & \multirow{2}{*}{ MANFAAT } & \multicolumn{4}{|c|}{ ESTIMASI BIAYA } \\
\hline & & & \multicolumn{2}{|c|}{ INVESTASI } & \multicolumn{2}{|c|}{ PERAWATAN/BULAN } \\
\hline \multirow{4}{*}{1} & \multirow{4}{*}{$\begin{array}{l}\text { Efluen WWT } \\
\text { diproses dengan } \\
\text { Reverse Osmosis }\end{array}$} & $\begin{array}{c}\text { Instalasi } \\
\text { sederhana }\end{array}$ & Instalasi RO & $\begin{array}{c}\mathrm{Rp} \\
170.000 .000\end{array}$ & $\begin{array}{c}\text { Ganti } \\
\text { Membran }\end{array}$ & Rp 20.000 .000 \\
\hline & & $\begin{array}{c}\text { Memenuhi } \\
\text { parameter } \\
\text { air industri }{ }^{*}{ }^{*}\end{array}$ & $\begin{array}{l}\text { Modifikasi } \\
\text { Pipa }\end{array}$ & $\begin{array}{c}\mathrm{Rp} \\
100.000 .000\end{array}$ & $\begin{array}{c}\text { Uji air di } \\
\text { lab eksternal }\end{array}$ & Rp 500.000 \\
\hline & & $\begin{array}{l}\text { Umur ekonomis: } \\
10 \text { tahun }\end{array}$ & & & $\begin{array}{l}\text { Upah } \\
\text { Lembur } \\
2 \mathrm{MP}\end{array}$ & Rp 720.000 \\
\hline & & $\begin{array}{l}\text { Nilai sisa alat: } \\
\text { Rp 28.991.029 }\end{array}$ & & & & \\
\hline \multicolumn{3}{|c|}{ Total } & \multicolumn{2}{|c|}{ Rp 270.000 .000} & \multicolumn{2}{|c|}{ Rp 21.220.000 } \\
\hline \multirow{5}{*}{2} & \multirow{5}{*}{$\begin{array}{l}\text { Efluen WWT } \\
\text { diproses dengan } \\
\text { Reverse Osmosis, } \\
\text { Karbon aktif dan } \\
\text { Mikrofiltrasi }\end{array}$} & $\begin{array}{l}\text { Instalasi sedikit } \\
\text { rumit }\end{array}$ & Instalasi RO & $\begin{array}{c}\mathrm{Rp} \\
170.000 .000\end{array}$ & $\begin{array}{c}\text { Ganti } \\
\text { Membran }\end{array}$ & Rp 5.000 .000 \\
\hline & & $\begin{array}{l}\text { Memenuhi } \\
\text { parameter } \\
\text { air industri }{ }^{*}{ }^{*}\end{array}$ & $\begin{array}{c}\text { Instalasi } \\
\text { Karbon } \\
\text { Aktif }\end{array}$ & Rp 7.100 .000 & $\begin{array}{l}\text { Ganti } \\
\text { Karbon } \\
\text { Aktif }\end{array}$ & Rp 500.000 \\
\hline & & $\begin{array}{l}\text { Umur ekonomis: } \\
10 \text { tahun }\end{array}$ & $\begin{array}{l}\text { Instalasi } \\
\text { Mikrofilter }\end{array}$ & Rp 5.000.000 & $\begin{array}{c}\text { Ganti } \\
\text { Mikrofilter }\end{array}$ & Rp 900.000 \\
\hline & & $\begin{array}{l}\text { Nilai sisa alat: } \\
\text { Rp } 30.290 .256^{*}\end{array}$ & $\begin{array}{l}\text { Modifikasi } \\
\text { Pipa }\end{array}$ & $\begin{array}{c}R p \\
100.000 .000\end{array}$ & $\begin{array}{c}\text { Uji air di } \\
\text { lab ekstemal }\end{array}$ & Rp 500.000 \\
\hline & & & & & $\begin{array}{l}\text { Upah } \\
\text { Lembur } \\
2 \mathrm{MP}\end{array}$ & Rp 720.000 \\
\hline \multicolumn{3}{|c|}{ Total } & \multicolumn{2}{|c|}{$\operatorname{Rp} 282100.000$} & \multicolumn{2}{|c|}{ Rp 7.620 .000} \\
\hline \multirow{6}{*}{3} & \multirow{6}{*}{$\begin{array}{l}\text { Efluen WWT } \\
\text { diproses dengan } \\
\text { Reverse Osmosis, } \\
\text { Karbon aktif, } \\
\text { Mikrofiltrasi dan } \\
\text { Ultra Violet }\end{array}$} & Instalasi rumit & Instalasi RO & $\begin{array}{c}\mathrm{Rp} \\
170.000 .000\end{array}$ & $\begin{array}{c}\text { Ganti } \\
\text { Membran }\end{array}$ & Rp 5.000 .000 \\
\hline & & \begin{tabular}{c} 
Memenuhi \\
parameter \\
air layak minum \\
\multirow{22}{*}{}
\end{tabular} & $\begin{array}{l}\text { Instalasi } \\
\text { Karbon } \\
\text { Aktif }\end{array}$ & Rp 7.100 .000 & $\begin{array}{l}\text { Ganti } \\
\text { Karbon } \\
\text { Aktif }\end{array}$ & Rp 500.000 \\
\hline & & $\begin{array}{l}\text { Umur ekonomis: } \\
10 \text { tahun }\end{array}$ & $\begin{array}{c}\text { Instalasi } \\
\text { Mikrofilter }\end{array}$ & Rp 5.000 .000 & $\begin{array}{c}\text { Ganti } \\
\text { Mikrofilter }\end{array}$ & Rp 900.000 \\
\hline & & $\begin{array}{l}\text { Nilai sisa alat: } \\
\text { Rp } 31.900 .869^{73}\end{array}$ & $\begin{array}{l}\text { Modifikasi } \\
\text { Pipa }\end{array}$ & $\begin{array}{c}R p \\
100.000 .000\end{array}$ & $\begin{array}{l}\text { Perawatan } \\
\text { Ultra Violet }\end{array}$ & Rp 155.000 \\
\hline & & & $\begin{array}{l}\text { Instalasi } \\
\text { Ultra Violet }\end{array}$ & Rp 15.000 .000 & $\begin{array}{c}\text { Uji air di } \\
\text { lab eksternal }\end{array}$ & Rp 500.000 \\
\hline & & & & & $\begin{array}{l}\text { Upah } \\
\text { Lembur } \\
2 \mathrm{MP}\end{array}$ & Rp 720.000 \\
\hline \multicolumn{3}{|c|}{ Total } & \multicolumn{2}{|c|}{ Rp 297.100.000 } & \multicolumn{2}{|c|}{ Rp 7.775.000 } \\
\hline
\end{tabular}


yang meliputi Efluen WWT diproses dengan Reverse Osmosis, Efluen WWT diproses dengan Reverse Osmosis, Karbon aktif dan Mikrofiltrasi, Efluen WWT diproses dengan Reverse Osmosis, Karbon aktif, Mikrofiltrasi dan Ultra Violet. Adapun perbandingan ketiga alternatif metode pengolahan air bersih adalah sebagai berikut :

\section{Alternatif Teknologi 1}

Alternatif ini menggunakan reverse osmosis untuk mengolah air efluen menjadi air bersih yang memenuhi parameter air bersih untuk industri. Namun beban kerja dari alternatif teknologi ini terlalu berat dikarenakan nilai parameter air efluen bervariasi sehingga menyebabkan membran reverse osmosis sering tersumbat. Penyumbatan pada membran reverse osmosis pula yang menyebabkan biaya perawatan untuk sistem ini menjadi mahal diantara ketiga alternatif yang ada.

2. Alternatif Teknologi 2

Alternatif ini menggunakan reverse osmosis, karbon aktif, dan mikrofiltrasi untuk mengolah air efluen menjadi air bersih yang memenuhi parameter air bersih untuk industri. Beban kerja dari alternatif teknologi ini ringan dikarenakan adanya karbon aktif yang berfungsi untuk menurunkan penyebab kerak dan mikrofiltrasi yang berfungsi untuk menyaring partikel berukuran 1 mikron. Air hasil pengolahan ini tidak bisa digunakan untuk kegiatan wudhu, namun hal ini bisa diabaikan karena presentase pemakaiannya terlalu kecil jika dibandingkan dengan kegiatan yang

Perhitungan : lain. Biaya perawatan untuk alternatif ini paling murah diantara ketiga alternatif.

3. Alternatif Teknologi 3

Alternatif ini menggunakan reverse osmosis, karbon aktif, mikrofiltrasi, dan ultraviolet untuk mengolah air efluen menjadi air bersih yang memenuhi parameter air bersih layak minum. Beban kerja dari alternatif teknologi ini ringan dikarenakan adanya karbon aktif yang berfungsi untuk menurunkan penyebab kerak, mikrofiltrasi yang berfungsi untuk menyaring partikel berukuran 1 mikron, dan ultraviolet yang berfungsi untuk membunuh bakteri. Air hasil pengolahan ini bisa digunakan untuk kegiatan wudhu. Biaya investasi awal untuk alternatif ini paling mahal diantara ketiga alternatif yang ada dengan biaya perawatan setiap bulan pada tingkat sedang.

\section{Perhitungan Net Present Value \& Pemilihan Alternatif Terbaik}

Berdasarkan ketiga alternatif teknologi pengolahan air, kemudian dihitung investasinya dengan menggunakan $\mathrm{Net}$ Present Value, sebagaimana pada persamaan (2), yang hasilnya disajikan pada tabel 2. Setelah dilakukan perhitungan NPV terhadap ketiga alternatif teknologi tersebut, maka didapatkan bahwa alternatif 2 dan alternatif 3 bernilai positif sehingga teknologi ini layak untuk dilakukan investasi sedangkan alternatif 1 bernilai negatif sehingga teknologi ini tidak layak untuk dilakukan investasi. Berdasarkan 2 alternatif solusi yang bernilai positif, langkah selanjutnya adalah melakukan analisis incremental rate of return (Incremental IRR) untuk memilih alternatif yang paling ekonomis.

$$
\begin{aligned}
N P V_{(3-2)} & =-(\text { Selisih Investasi })+(\text { Selisih Untung }) \times(\mathrm{P} / \mathrm{A}, \mathrm{i} \%, \mathrm{~N})=0 \\
& =-(297.100 .000-282.100 .000)+(183.446 .460-181.586 .460) \times \mathrm{P} / \mathrm{A}, \mathrm{i} \% \\
= & -(15.000 .000)+(1.860 .000) \times \mathrm{P} / \mathrm{A}, \mathrm{i} \% \\
\mathrm{P} / \mathrm{A} \mathrm{i} \% & =\frac{-15.000 .000}{-1.860 .000} \\
= & 8,0645
\end{aligned}
$$


Tabel 2. Hasil Perhitungan NPV

\begin{tabular}{|l|r|r|r|}
\hline Teknologi & \multicolumn{1}{|c|}{ Alternatif 1 } & \multicolumn{1}{c|}{ Alternatif 2 } & \multicolumn{1}{c|}{ Alternatif 3 } \\
\hline Investment (I) & 270.000 .000 & 282.100 .000 & 297.100 .000 \\
\hline Annual Benefit (AB) ${ }^{*}$ ) & 274.886 .460 & 274.886 .460 & 274.886 .460 \\
\hline Annual Cost (AC) & 254.640 .000 & 91.440 .000 & 93.300 .000 \\
\hline Nilai Sisa Alat (S) & 28.991 .029 & 30.290 .257 & 31.900 .870 \\
\hline Umur Ekonomis (N) & 10 Tahun & 10 Tahun & 10 Tahun \\
\hline Overhoul Tahun ke-5 (OH) $)_{5}$ & 20.000 .000 & 30.000 .000 & 40.000 .000 \\
\hline Suku Bunga (i) & $7 \%$ & $7 \%$ & $7 \%$ \\
\hline Net Present Value (NPV) & -127.319 .174 & 1.000 .362 .909 & 965.987 .868 \\
\hline
\end{tabular}

Jika dilihat pada tabel suku bunga, nilai 8,0645 berada pada persentase $4 \%-5 \%$,

kemudian dilakukan interpolasi untuk mendapatkan angka yang pasti.

Perhitungan Interpolasi :

$$
\frac{X-X_{1}}{X_{2}-X_{1}}=\frac{Y-Y_{1}}{Y_{2}-Y_{1}} \Longrightarrow \frac{X-4 \%}{5 \%-4 \%}=\frac{8,0645-7,7217}{8,1109-7.7217}=4,8 \%
$$

Karena i\% perhitungan $(4,8 \%)$ lebih kecil dari $\mathrm{i} \%$ acuan (7\%), maka yang dipilih adalah alternatif teknologi 2. Untuk menjaga sisi objektifitas kelayakan dan konsistensi dari suatu investasi, maka dilakukan juga penilaian oleh Manager PSE dan seorang peneliti external terhadap ketiga alternatif teknologi pengolahan air tersebut dengan parameter berbagai aspek seperti yang tersaji pada tabel 3 , dimana alternatif teknologi 2 memiliki skor terbesar yaitu 3,85 sehingga memperkuat pilihan sesuai hasil perhitungan NPV dan IRR. Setelah diperkuat oleh data-data diatas maka didapatkan bahwa alternatif teknologi 2 memiliki nilai terbaik sehingga teknologi ini akan diterapkan di PT YMI untuk proses pengolahan air bersih dengan memanfaatkan air efluen sebagai bahan baku.

Tabel 3. Penilaian Ketiga Alternatif Teknologi Pengolahan Air

\begin{tabular}{|c|c|c|c|c|c|c|c|}
\hline \multirow{2}{*}{ Aspek Penilaian } & \multirow{2}{*}{$\begin{array}{l}\text { Bobot } \\
\text { (B) }\end{array}$} & \multicolumn{2}{|c|}{ Alternatif 1} & \multicolumn{2}{|c|}{ Alternatif 2} & \multicolumn{2}{|c|}{ Alternatif 3} \\
\hline & & Nilai (N) & $B \times N$ & Nilai (N) & $B \times N$ & Nilai (N) & $\mathrm{B} \times \mathrm{N}$ \\
\hline Kebutuhan (need) & 0.25 & 4 & 1.00 & 4 & 1.00 & 5 & 1.25 \\
\hline Harga (price) & 0.35 & 4 & 1.40 & 3 & 1.05 & 2 & 0.70 \\
\hline $\begin{array}{l}\text { Keandalan } \\
\text { (reliability) }\end{array}$ & 0.20 & 3 & 0.60 & 4 & 0.80 & 4 & 0.80 \\
\hline $\begin{array}{l}\text { Pencegahan } \\
\text { (preventive) }\end{array}$ & 0.20 & 2 & 0.40 & 5 & 1.00 & 4 & 0.80 \\
\hline Total & 1.00 & & 3.40 & & 3.85 & & 3.55 \\
\hline
\end{tabular}

Keterangan : 1 =sangat tidak baik; $2=$ tidak baik; $3=$ sedang; $4=$ baik; 5 sangat baik

\section{Rancangan Penampungan Air Bersih dan Rangkaian Pipa}

Untuk membantu kelancaran pendistribusian air bersih di seluruh area PT YMI, maka dibuatkan suatu penampungan air bersih yang terpusat. Penampungan air bersih dapat dilihat pada gambar 3 yang memiliki spesifikasi sebagai berikut :

a. Torn Air

- Kapasitas : 5000 L
- Bahan : Polipropilen + Coating

b. Rangka Tiang

- Kaki-kaki : IWF 200 x 100 x 5.5 x $8 \mathrm{~mm}$, hasil pengujian: $0,0098 \rightarrow$ OK.

- Hor. Bracing : UNP 150 x 75 × 6.5 $\mathrm{mm}$, hasil pengujian: $0,0043 \rightarrow \mathrm{OK}$

- Bracing : ES 60 × 60 × 6 mm, hasil pengujian: $0,074 \rightarrow \mathrm{OK}$ 


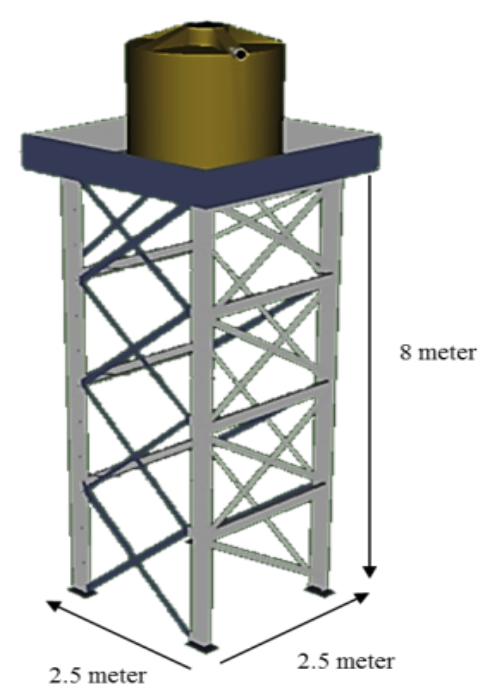

(a)

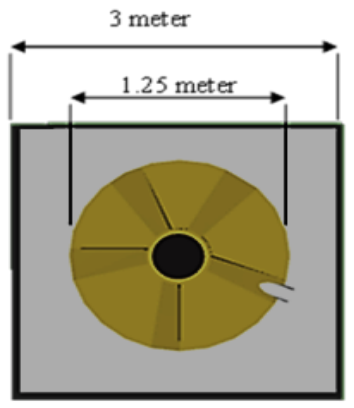

(b)

Gambar 3. (a) Water Torn (b) Water Torn Tampak Atas.

Dalam mendistribusikan air diperlukan sebuah sistem perpipaan. Sistem perpipaan yang akan dibuat meliputi instalasi pipa saluran dari WWT menuju saluran flushing toilet area produksi, office, lobby, klinik, dan receiving. Lalu saluran pipa tempat istirahat area depan dan belakang. Lalu saluran pipa menuju area penyiraman tanaman di dekat area kantin, taman belakang, dan security. Lalu saluran pipa pada kolam ikan dan pool painting. Lalu saluran pipa pada tempat pencucian mobil. Pada gambar 4 tersaji denah perpipaan dari PT YMI untuk mengalirkan air hasil pemurnian dari sistem R.O ke unit-unit sumber air.

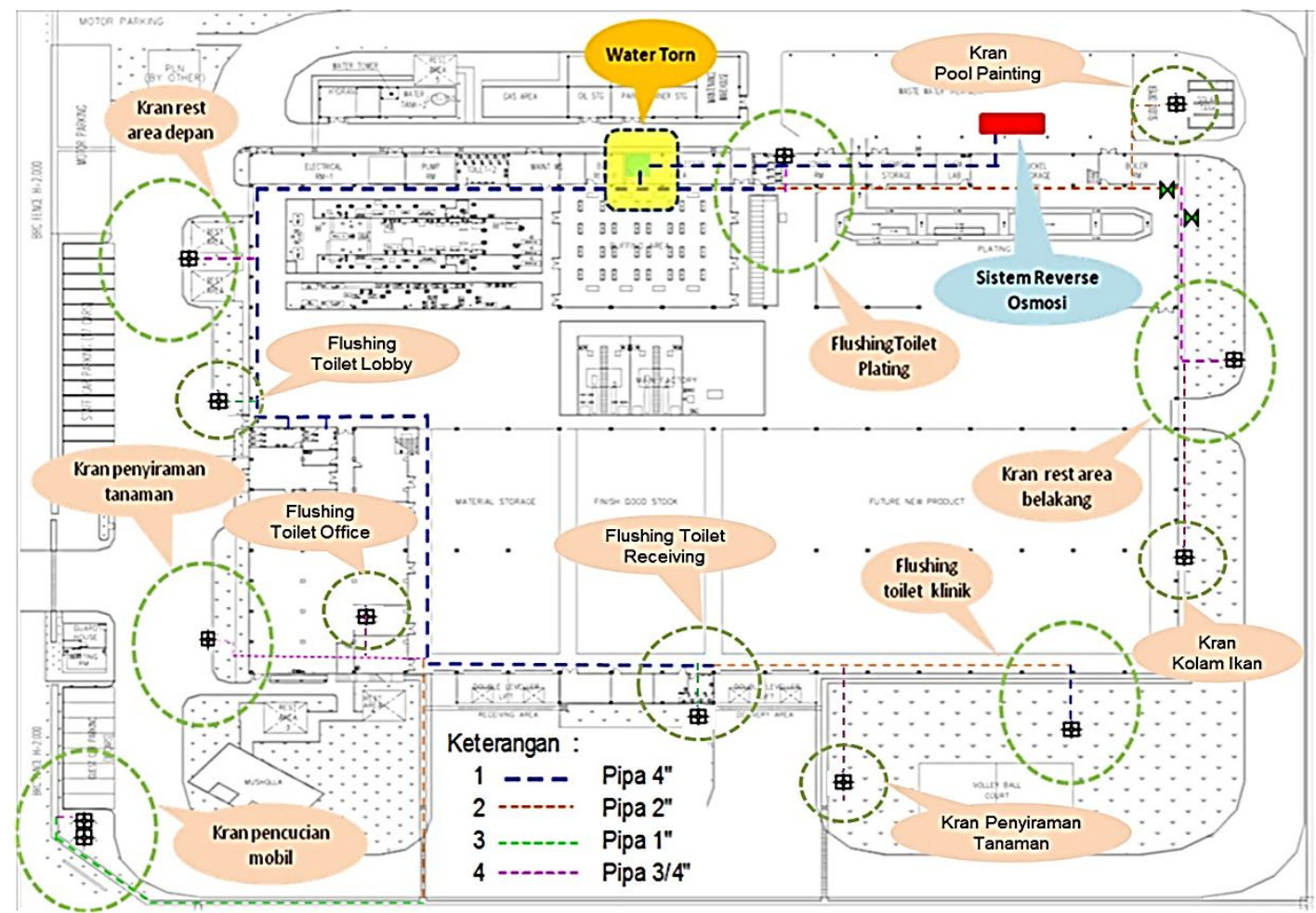

Gambar 4. Diagram Alur Pipa Air Bersih PT YMI (Sumber : PT YMI, 2016) 
Performa Pemakaian Air dan Dengan mengambil data setelah mass Pencapaian Target

Pada gambar 5 tersaji data rata-rata pembuangan air efluen dan pemakaian air bersih PT YMI selama tahun 2016. production, maka bisa dilakukan sebuah perhitungan untuk melihat pencapaian efisiensi, yaitu :

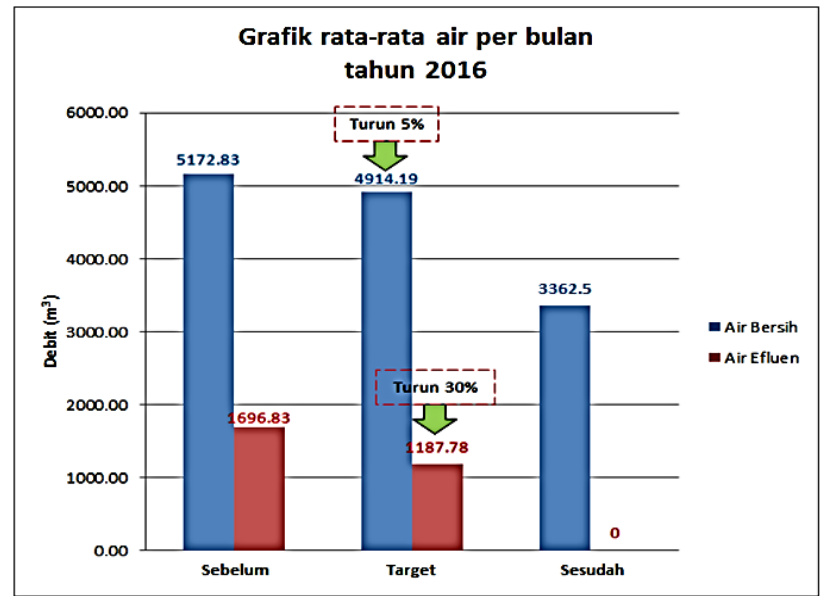

Gambar 5. Grafik rata-rata Pemakaian Air Bersih dan Pembuangan Air Efluen per bulan

1. Efisiensi Pemakaian Air Bersih

$$
\begin{aligned}
\% \text { efisiensi } & =\frac{(\text { Pemakaian air sebelum }- \text { Pemakaian air sesudah }) \times 100 \%}{\text { Pemakaian air sebelum }} \\
& =\frac{\left(5172,83 \mathrm{~m}^{3}-3362,50 \mathrm{~m}^{3}\right) \times 100 \%}{5172,83 \mathrm{~m}^{3}} \\
& =34,99 \%
\end{aligned}
$$

2. Efisiensi Pembuangan Air Efluen

$\%$ efisiensi $=$ (Pembuangan air sebelum-Pembuangan air sesudah $) \times 100 \%$

$$
\begin{aligned}
& =\frac{\left(1696,83 \mathrm{~m}^{3}-0 \mathrm{~m}^{3}\right) \times 100 \%}{1696,83 \mathrm{~m}^{3}} \\
& =100 \%
\end{aligned}
$$

Pencapaian efisiensi untuk pemakaian air bersih yaitu sebesar $34.99 \%$. Pencapaian ini melebihi target yang diberikan oleh pihak manajemen yaitu sebesar 5\%. Sedangkan pencapaian efisiensi untuk pembuangan air efluen yaitu sebesar $100 \%$. Pencapaian ini melebihi target yang diberikan oleh pihak manajemen dan tim internal audit AGC yaitu sebesar $30 \%$.

\section{Analisis Biaya}

Berikut adalah rincian operasional sistem Reverse Osmosis (RO):
- Waktu Operasional= 16 jam per hari, 26 hari kerja per bulan.

- $\quad$ Pompa Feed Water $=1100$ watt $=1.1$ $\mathrm{kW}$

- Pompa Booster $=4000$ watt $=4 \mathrm{~kW}$

- Pompa Transfer $=1007$ watt $=1.07$ $\mathrm{kW}$

- Asumsi Harga Listrik = Rp 1.500 per $\mathrm{kWH}$.

Maka konsumsi listrik yang digunakan oleh sistem RO adalah :

(1) Konsumsi Total Pompa $=(1.1+4+$ 1.07) $\mathrm{kWH}=6.17 \mathrm{kWH}$

(2) Lama Pemakaian $=6.17 \mathrm{~kW}$ x $16=$ 
$98.72 \mathrm{kWH}$

(3) Biaya Listrik $=98.72 \mathrm{kWH} \times \mathrm{Rp}$ $1.500 / \mathrm{kWH}$ $=\operatorname{Rp~} 148.080 /$ hari $=\operatorname{Rp} 148.080 \times 26=\operatorname{Rp} 3.850 .080,-$ /bulan.

Sedangkan biaya perawatan dari sistem RO per bulan, meliputi biaya penggantian dan pembersihan spare part dari alat RO, serta biaya man power. Adapun Perincian biaya adalah sebagai berikut :

a. Biaya Penggantian Membran= Rp.5.000.000

b. Biaya Penggantian Mikrofiltrasi= Rp. 900.000

c. Biaya Karbon Aktif

Rp. 500.000

d. Biaya Analisa Lab. Eksternal = Rp. 500.000

e. Biaya lembur 2 Man Power= Rp. 720.000

Total = Rp.7.620.000,- / bulan.

Total biaya operasional per bulan adalah biaya energi listrik ditambah dengan biaya perawatan sistem RO, yaitu Rp 3.850.080,$+\operatorname{Rp} 7.620 .000,-=\operatorname{Rp} 11.470 .172,-$ I bulan.

\section{Analisis Payback Period}

Analisis payback period bertujuan untuk mengetahui pada bulan ke berapa terjadinya kondisi titik balik modal, dimana perhitungannya menggunakan persamaan (1).

- Diketahui :

- Investasi Awal : Rp 282.100.000

- Benefit : Rp 23.591.675

- Operational $\quad:$ Rp 11.470 .172

Perhitungan Payback Period (PP) :

$$
\begin{aligned}
P P & =\frac{\text { Investasi Awal }}{\text { Benefit-Opeational }} \\
\mathrm{PP} & =\frac{282.100 .000}{23.591 .675-11.470 .172} \\
& =23,27 \text { bulan } \approx 24 \text { bulan }
\end{aligned}
$$

Jika dihitung dari awal produksi massal pemurnian air yaitu bulan oktober 2016 maka payback period akan terjadi pada bulan Oktober 2018.

\section{Pengendalian Kualitas Sistem Pengolahan Air}

Untuk menjaga performa dari teknologi RO yang telah diterapkan, maka dilakukan beberapa pengendalian kualitas, antara lain meliputi sebagai berikut:
a. Instruksi Kerja (IK)
b. Daily Control Checksheet
c. Jadwal Pencegahan
d. Troubleshooting
e. Pengujian Laboratorium Eksternal.

\section{KESIMPULAN}

Proyek pengolahan air bersih di PT. YMI, yang harus dilaksanakan adalah teknologi pengolahan air berdasarkan alternatif teknologi 2 yang terdiri dari rangkaian reverse osmosis yang mampu menyaring partikel sampai ukuran $10^{-4} \mu \mathrm{m}$, karbon aktif dan mikrofiltrasi berfungsi untuk mencegah pemampatan pada membran reverse osmosis (fouling). Alternatif teknologi ini memiliki efisiensi pemakaian air bersih sebesar $34.99 \%$ dengan biaya operasional dan pemakaian spare part sebesar Rp 11.740.172,- /bulan, serta pemasukan dengan teknologi ini sebesar $\mathrm{Rp}$ 23.591.675,- /bulan sehingga menghasilkan keuntungan sebesar Rp 12.121.503,- /bulan. Hal ini sangat bermanfaat bagi perusahaan karena tidak harus mengeluarkan biaya untuk pembuangan limbah cair yang berharga 0,55 USD untuk $1 \mathrm{~m}^{3}$ limbah.

\section{DAFTAR PUSTAKA}

Hutasoit, Febry. (2011). Penting Penerapan Efisiensi Biaya. Jakarta : EGC.

Kucera, Jane. (2010). Reverse Osmosis Industrial Aplication.. Canada: Screvener Pullishing LLC.

Osterwalder, Alexander. (2012). Bussiness Model Generation. Jakarta : Elex Media Komputindo. 